\title{
Pre-Treatment of High Free Fatty Acids Oils by Chemical Re-Esterification for Biodiesel Production-A Review
}

\author{
Godlisten G. Kombe ${ }^{1 *}$, Abraham K. Temu' ${ }^{1}$, Hassan M. Rajabu ${ }^{2}$, \\ Godwill D. Mrema ${ }^{1}$, Jibrail Kansedo ${ }^{3}$, Keat Teong Lee ${ }^{3}$ \\ ${ }^{1}$ Department of Chemical and Mining Engineering, College of Engineering and Technology, \\ University of Dar es Salaam, Dar es Salaam, Tanzania \\ ${ }^{2}$ Department of Energy Engineering, College of Engineering and Technology, \\ University of Dar es Salaam, Dar es Salaam, Tanzania \\ ${ }^{3}$ School of Chemical Engineering, Universiti Sains Malaysia, Pinang, Malaysia \\ Email: *kombe@live.com, atemu@udsm.ac.tz,hmrajabu@udsm.ac.tz, \\ mremag@udsm.ac.tz, epa2007@gmail.com, chktlee@eng.usm.my
}

Received July 29, 2013; revised August 29, 2013; accepted September 10, 2013

Copyright (C) 2013 Godlisten G. Kombe et al. This is an open access article distributed under the Creative Commons Attribution License, which permits unrestricted use, distribution, and reproduction in any medium, provided the original work is properly cited.

\begin{abstract}
Non edible oil sources have the potential to lower the cost of biodiesel. However, they usually contain significant high amounts of free fatty acids (FFA) that make them inadequate for direct base catalyzed transesterification reaction (where the FFA content should be lower than 3\%). The present work reviews chemical re-esterification as a possible method for the pre-treatment of high FFA feedstock for biodiesel production. The effects of temperature, amount of glycerol, type and amount of catalyst have been discussed. Chemical re-esterification lowers FFA to acceptable levels for transesterification at the same time utilizing the glycerol by product from the same process. Further researches have been proposed as a way forward to improve the process kinetics and optimization so as to make it more economical.
\end{abstract}

Keywords: Chemical Re-Esterification; High Free Fatty Acid; Glycerolysis; Biodiesel Feedstock

\section{Introduction}

The worldwide worry about the protection of environment and the dependence on fossil fuel has given rise to development of alternative energy sources as substitute for traditional fossil fuels. Fossil fuel sources are nonrenewable, and will be exhausted in the near future. According to Alekett [1] the world's oil reserves are up to $80 \%$ less than predicted, which calls for alternative sources of energy. Biodiesel is one of the renewable energy fuel sources alternatives to the conventional petroleum diesel. It is simply produced by transesterification process whereby the vegetable oil or animal fat (Triglyceride) reacts with alcohol in presence of catalyst or without catalyst to give the corresponding alkyl esters of the fatty acid mixture that is found in the parent vegetable oil or animal fat $[2,3]$. Transesterification reaction can be uncatalyzed, base-catalyzed, acid-catalyzed or enzymecatalyzed.

Research on biodiesel production has captured the attention of different researchers with focus on heteroge-

\footnotetext{
"Corresponding author.
}

neous catalysts which have received considerable attention [4-9]. Unfortunately these studies did not lead to the development of catalysts with high activity, good reusability and stability in order to replace the homogenous catalysts, such as the sodium methoxide or hydroxide [10-12]. Today, homogeneous base-catalyzed transesterification process is widely used industrially due to the fact that, it is kinetically much faster and it has been proven to be economically viable [13]. According to the report by Bacovsky, Körbitz, Mittelbach and Wörgetter [14] on the status of biodiesel production technology, most of the commercialized biodiesel production technology utilizes homogeneous base-catalyzed transesterification. However, the main drawback of this technology is its sensitivity to the purity of feedstocks, especially water and free fatty acid content [15-17].

The use of edible grade oils as feedstocks competes with food supply in the long-term [18] and accounts for the higher price of biodiesel, since the cost of raw materials accounts for $60 \%$ to $80 \%$ of the total cost of biodiesel fuel [19-22]. One way of reducing the biodiesel production costs is to use the less expensive feedstocks 
mostly containing fatty acids such as inedible oils, animal fats, waste food oil and by-products of the refining vegetable oils [23-25]. However, feedstocks high in free fatty acid are not easily converted by homogeneous base transesterification, because of the concurrent soap formation of the free fatty acids with the catalyst. The excessive amount of soap formed significantly interferes with the washing process by forming emulsions, thus leading to substantial yield losses [26-30]. The reaction can only tolerate FFA content up to $3 \%$ in the feedstock without affecting the process negatively as suggested by Knothe, Van Gerpen and Krahl [31]. The free fatty acid (FFA) value lower than $3 \%$ is recommended for higher conversion efficiency [32]. The pre-treatments of non-edible oils for lowering the FFA in feedstock for base catalyzed transesterification are therefore inevitable.

The pre-treatment of high FFA with acid catalysis followed by base catalyzed transesterification has been proposed by several authors [2,23,33,34]. The process can lower a high FFA feedstock to $\leq 0.5 \%$ quickly and effectively. However, depending on the amount of FFA in the oils or fats; one-step pre-treatment may sometimes not reduce the FFA efficiently because of the high content of water produced during the reaction [35]. In this case, a mixture of alcohol and sulphuric acid can be added into the oils or fats three times (three-step preesterification) and the water must be removed before transesterification [36]. Van Gerpen, Shanks, Pruszko, Clements and Knothe [37] suggested the use of high molar ratios of alcohol to oil as high as 40:1 to dilute the water formed during pre-treatment, yet this will require more energy to recover the excess alcohol used. The water formed during the pre-treatment phase requires removal and the use of corrosive nature or catalysts commonly $\mathrm{H}_{2} \mathrm{SO}_{4}$ which requires high capital intensive reactors, has limited the application of the process.

The chemical re-esterification (glycerolysis) process has the capability of converting the free fatty acid back to their respective glyceride molecule. This technique involves adding glycerol to the high FFA feedstock and heating it to temperature of about $\left(200^{\circ} \mathrm{C}\right)$, with a metallic catalyst such as zinc chloride and zinc dust or without catalyst. The glycerol reacts with the FFAs to form monoglycerides, diglycerides and triglycerides [38]. It produces a low FFA feed that can be processed to methylesters using traditional homogeneous base transesterification technique. The advantage of this approach is that no alcohol is needed during the pre-treatment and the water formed from the reaction can be immediately vaporized and vented from the reaction mixture. The process has also the potential of utilizing glycerol, a by-product from transesterification and thereby lowers the cost of biodiesel. However, the drawbacks of this method are its high temperature requirement and rela- tively slow reaction rate [37]. Although chemical re-esterification has a potential to lower the high FFA feedstock for homogeneous base catalyzed transesterification. The re-esterification method has not been studied from the standpoint of the extent of de-acidification for biodiesel production. The literatures on the applicability of this process as a high FFA pre-treatment for biodiesel are hard to find. It is the purpose of this paper to review the applicability of the glycerolysis process as a pre-treatment method for lowering the FFA to the acceptable level of 3\% for Biodiesel production using homogenous base catalyzed transesterification.

\section{Background of Chemical Re-Esterification}

The chemical re-esterification process is one of the old high FFA pre-treatment methods for food grade products. It has been in existence for more than centuries [39]. It converts the free fatty acid into neutral glycerides by reesterification with the free hydroxyl groups remaining in the oil (or with added hydroxyl groups from glycerol) at a high temperature, with or without catalyst [38]. The reaction starts with the formation of monoglycerides, which is further esterified to diglycerides and then to a triglyceride [40]. Contrary to loss of oils during pretreatment by other FFA pre-treatment processes, the reesterification increases the yield of neutral oil. The water formed during reaction lead to the establishment of equilibrium between the reactants under the experimental conditions and it should therefore be removed. Several approaches have been proposed to remove water in the reaction mixture. The use of an inert gas or air and to maintain vacuum have been suggested to eliminate water from the reaction mixture [39].

\section{Factors Affecting the Chemical Re-Esterification Reaction}

The reaction temperature, amount and type of catalyst, and amount of glycerol are the main factors that are said to affect the yield of the chemical re-esterification process in converting free fatty acid into triglycerides.

\subsection{Effect of Temperature on Chemical Re-Esterification}

Literatures show that chemical re-esterification can occur at different temperatures, depending on the type oil used. Variable temperatures of $180^{\circ} \mathrm{C}, 220^{\circ} \mathrm{C}$ and $230^{\circ} \mathrm{C}$ were used by Felizardo et al. [41] in pre-treating acidulated soap stock of $50 \%$ FFA. It was found that temperature increase favors the reaction kinetics considerably faster at $230^{\circ} \mathrm{C}$. However, more significant difference in FFA drop seems to occur when the temperature increases from $180^{\circ} \mathrm{C}$ to $220^{\circ} \mathrm{C}$. The FFA content of the acidulated soap- 
stocks was reduced from $50 \%$ to $5 \%$ after $3 \mathrm{~h}$ of reaction at $200^{\circ} \mathrm{C}$. Similar temperature trend were also observed by $[39,42,43]$ in re-esterification of high FFA rice bran oil whereby the rate at which raw rice bran oil re-esterifies was maximum between $180^{\circ} \mathrm{C}$ and $200^{\circ} \mathrm{C}$. De and Bhattacharyya [44] show that the reaction temperature of $210^{\circ} \mathrm{C}$ was more effective than temperature below $200^{\circ} \mathrm{C}$ in re-esterifing rice bran oil containing high FFA $(9.5 \%$ to $35.0 \%$ ) with monoglycerides.

The reaction temperature was also found to influence the rate of re-esterification process by Ebewele, Iyayi and Hymore [45], in chemical re-esterification of high acidic rubber seed oil with $37.69 \%$ FFA. At low temperature of $150^{\circ} \mathrm{C}$ the FFA was lowered to about $7.03 \%$ in $6 \mathrm{~h}$. While at $200^{\circ} \mathrm{C}$, the FFA dropped to $1.5 \%$ over the same period. On increasing temperature further to $250^{\circ} \mathrm{C}$, the reduction in FFA was fastest within the first two hours. However, the FFA dropped to $3.88 \%$ after $6 \mathrm{~h}$ of the reaction time. It is supposed that there was a small degree of fat splitting at this elevated temperature after being held for $6 \mathrm{~h}$. The rate at which FFA re-esterifies was at its maximum between $200^{\circ} \mathrm{C}$ and $250^{\circ} \mathrm{C}$.

\subsection{Effect of Amount and Type of Catalyst}

The chemical re-esterification of free fatty acid is affected by the type and amount of catalyst used, although reaction can also proceed without catalyst [39]. An extensive research on different types of catalysts was done by Feuge, Kraemer and Bailey [46] whereby $\mathrm{AICI}_{2} \cdot 6 \mathrm{H}_{2} 0$, $\mathrm{Al}_{2} \mathrm{O}_{3}, \mathrm{SnO}_{2}, \mathrm{SbCl}_{3}, \mathrm{HgCl}_{2}, \mathrm{FeO}, \mathrm{NiCl}_{2} \cdot 6 \mathrm{H}_{2} \mathrm{O}, \mathrm{NaOH}$, $\mathrm{MgCl}_{2} \cdot 6 \mathrm{H}_{2} \mathrm{O}, \mathrm{MgO}, \mathrm{MnCl}_{2} \cdot 4 \mathrm{H}_{2} \mathrm{O}, \mathrm{PbCl}_{2}, \mathrm{ZnO}, \mathrm{FeCl}_{3} \cdot 6 \mathrm{H}_{2} \mathrm{O}$, $\mathrm{CdCl}_{2} \cdot 2.5 \mathrm{H}_{2} \mathrm{O}, \mathrm{PbO}, \mathrm{MnO}_{2}, \mathrm{ZnCl}_{2}, \mathrm{SnCl}_{2} \cdot 2 \mathrm{H}_{2} \mathrm{O}, \mathrm{SnCl}_{4} \cdot 5 \mathrm{H}_{2} \mathrm{O}$ and $\mathrm{HCl}$ were tried by chemical reesterification of the mixed fatty acids obtained by saponification of peanut oil with $90.3 \%$ FFA under reduced pressure $(20 \mathrm{mmHg})$ and at the temperature of $200^{\circ} \mathrm{C}$. Only $\mathrm{SnCl}_{2} \cdot 2 \mathrm{H}_{2} \mathrm{O}, \mathrm{SnCl}_{4} \cdot 5 \mathrm{H}_{2} \mathrm{O}$ and $\mathrm{ZnCl}_{2}$ were found to be excellent in catalytic activity and the FFA of oil drop from $90.3 \%$ to $2.8 \%, 2.4 \%$ and $3.5 \%$ respectively for $6 \mathrm{~h}$. When the reaction was uncatalyzed, the FFA drops to 5.34 after $8 \mathrm{~h}$ and at an elevated temperature of $241^{\circ} \mathrm{C}$.

The rate of re-esterification was observed to be slow in the absence of catalyst by Ebewele, Iyayi and Hymore [45]. In this reaction, FFA was reduced to $15.38 \%$ from $37.69 \%$ in $6 \mathrm{~h}$ without catalyst. However, on using zinc dust $(0.25 \%$ by weight of oil) and zinc chloride $(0.15 \%$ by weight of oil) significant reduction in FFA was achieved. Zinc dust lowered the FFA of rubber seed oil from $37.69 \%$ to $1.50 \%$ while Zinc chloride lowered the FFA to about $1.27 \%$ within $6 \mathrm{~h}$ of reaction time. No significant reduction of FFA was observed when the two catalysts were combined.

Felizardo et al. [41] tried metallic zinc and dehydrated zinc acetate as chemical re esterification catalysts. The catalysts concentrations used were $0.1 \%, 0.2 \%$ and $0.3 \% \mathrm{w} / \mathrm{w}$ of the acidulated soap stock. Both metallic zinc and dehydrated zinc acetate catalysts showed almost the same effect on reaction kinetics. On increasing catalyst dose the reaction kinetic was also increasing until a reaction time of $1 \mathrm{~h}$, however the final acidity did not seem to be affected after $1 \mathrm{~h}$. It was also shown that $2 \mathrm{~h}$ will be required to achieve the same drop of FFA without catalyst. The effect of the catalyst dose on re-esterification of rice bran oil with $50 \%$ and $70 \%$ excess glycerol was also investigated by Singh and Singh [43] with $7 \mathrm{~h}$ of reaction time. $\mathrm{SnCl}_{2}$ catalyst concentrations of $0.1 \%, 0.15 \%, 0.2 \%$, $0.25 \%$ and $0.3 \% \mathrm{w} / \mathrm{w}$ were used. At the stated conditions, $0.2 \% \mathrm{w} / \mathrm{w}$ catalyst concentration was found to be optimum in lowering the acid value of the rice bran oil in both $50 \%$ and $70 \%$ excess of glycerol. Bhattacharyya and Bhattacharyya [42] investigated the effect of two catalysts namely stannous chloride and an aromatic sulphonic acid (p-toluene sulphonic acid) on the extent of re-esterification of FFA in rice bran oil with added glycerol. The catalysts were shown to influence the re-esterification rate only during the initial $2 \mathrm{~h}$. The p-toluene sulphonic acid was found to be more effective by lowering the rice bran oil with $15 \%$ - $30 \%$ FFA to low levels $(1.6 \%-4.0 \%)$ by reesterification with glycerol.

Wang, et al. [47] tried the super acid solid catalyst $\mathrm{SO}_{4}^{2}-/ \mathrm{ZrO}_{2}-\mathrm{Al}_{2} \mathrm{O}_{3}$ in the chemical re-esterification before homogeneous base transesterification. The FFA in the waste cooking oil with an acid value of $88.4 \mathrm{mg} \mathrm{KOH} / \mathrm{g}$ was lowered to $1.414 \mathrm{mg} \mathrm{KOH} / \mathrm{g}$. The re-esterification efficiency was found to be $98.4 \%$. The catalyst showed good activity in catalyzing the re-esterifying waste cooking oil by glycerol. Their work also shows the advantages of easy separation of excess glycerol and less catalyst loading $(0.3 \% \mathrm{w} / \mathrm{w})$.

\subsection{Effect of Amount of Glycerol}

The effects of amount glycerol on the re-esterification reaction was studied by Felizardo et al. [41]. The experiments were performed at $220^{\circ} \mathrm{C}$ with a glycerol excess of $4 \%, 11 \%$ and $52 \%$. The use of more than $10 \%$ (molar ratio glycerin/FFA $=1.10)$ excess glycerol did not show any improvements in the reaction kinetics at a temperature of $220^{\circ} \mathrm{C}$.

In their study, Ebewele, Iyayi and Hymore [45], the stoichiometric amount of glycerol $(4.3 \% \mathrm{w} / \mathrm{w}$ of oil) in re-esterifing rubber seed oil of $37.69 \%$ FFA was shown to be significant in FFA reduction as compared to when no glycerol was used in the reaction. However, using $5.6 \% \mathrm{w} / \mathrm{w}$ of oil that is $30 \%$ excess of glycerol there was no significant improvement in FFA reduction as compared to the stoichiometric amount of glycerol. With $30 \%$ excess of glycerol, the rate of FFA reduction was rapid during the initial $2 \mathrm{~h}$ of reaction and thereafter de- 
creases considerably. This could possibly due to high reesterification reaction occurring between the hydroxyl groups from the added glycerol and FFA at the initial stage which leads to an increase in triglycerides content. A reduction in FFA from $37.69 \%$ to $1.5 \%$ was achieved in a reaction time of $6 \mathrm{~h}$ with $4.3 \%$ glycerol (stoichiometric amounts) at $200^{\circ} \mathrm{C}$ while under the same reaction condition and time the FFA dropped from $37.69 \%$ to about $15 \%$ when no glycerol was used. In this case reduction in FFA content is thought to be the reaction between FFA and the free hydroxyl groups remaining in the oil (Bhosle and Subramanian, 2005).

Bhattacharyya and Bhattacharyya [42] studied the effect of the amount glycerol on the extent of re-esterification of raw rice bran oil. The addition of glycerol was shown to increase the rate of reaction. The excess theoretical amounts of glycerol used were 10\%,30\% and $50 \%$. After $6 \mathrm{~h}$ of reaction, the FFA was reduced from $15.3 \%$ to $4 \%$ by using $50 \%$ excess amount of glycerol while the drop in FFA was from $15.3 \%$ to $6 \%, 5.6 \%$ and $4.8 \%$ for $10 \%, 20 \%$ and $50 \%$ excess glycerol, respectively.

Singh and Singh [43] tried to use 50\%, 70\% and 100\% in excess of the theoretical amount of glycerol required in re-esterification of rice bran oil with acid value of 24.3 $\mathrm{mg} \mathrm{KOH} / \mathrm{g}$. When using 50\% excess glycerol, the drop in acid value was about $19.3 \%$ at $200^{\circ} \mathrm{C}$ for $6 \mathrm{~h}$. On increasing the excess glycerol up to $70 \%$, the re-esterification rate was faster and the maximum reduction in acid value was $20.2 \%$ at $200^{\circ} \mathrm{C}$ within $4 \mathrm{~h}$. The use of $100 \%$ excess glycerol followed similar trend to that of $70 \%$ excess glycerol. However, the impact of increasing the amount of glycerol was not encouraging as the maximum drop in acid value was only $20 \%$ after $5 \mathrm{~h}$.

\section{Applicability of Chemical Re-Esterification in Biodiesel Production}

The chemical re-esterification can lower the high FFA content in biodiesel for homogeneous base catalyzed transesterification technology as shown in Table 1. It is possible to lower the FFA of the oil to less than $3 \%$, which is an acceptable requirement for efficient production of biodiesel with homogeneous base transesterification. Sousa, Lucena and Fernandes [48] use the glycerol by product from transesterification to re-esterify castor oil with an FFA of $2.36 \%$. The high solubility of castor oil in glycerol due to hydroxyl group on the castor fatty acid glycerol makes it possible to lower the FFA to $0.22 \%$ for $2 \mathrm{~h}$ at $120^{\circ} \mathrm{C}$ without catalyst. Their results confirmed that glycerol (produced during the transesterification reaction) can be used to re-esterify the oil before its use in the production of biodiesel. In most of the reviewed literatures, the process has been used mostly in producing edible grade products whereby sensory properties and colour are of importance and therefore limit further exploration of different catalysts which are not good for edible grade product. Therefore, more researches in understanding the kinetics, application of different catalysts and optimizing process are still required.

\section{Conclusion}

The reviewed literature proved that the chemical re-esterification can be used as a pre-treatment method for high FFA feedstock for biodiesel production. In fact, the process shows the potentiality of reducing FFA to less than $3 \%$ which is required for homogeneous base catalyzed transesterification. This process can also utilize the glycerol from the transesterification process and would therefore lower the cost of biodiesel. There is a need for further research on this area, since little is still known on the optimization of the process especially for processing biodiesel feedstock whereby sensory properties and color are not important. The chemical re-esterification can be more easily implemented than acid esterification and thereby avoids the need for neutralization and alcohol

Table 1. The effect of chemical re-esterification on the final amount of FFA.

\begin{tabular}{|c|c|c|c|c|c|c|c|}
\hline Oil type & Time (h) & $\begin{array}{l}\text { Temperature } \\
\left({ }^{\circ} \mathrm{C}\right)\end{array}$ & Catalyst & $\begin{array}{l}\text { Amount of } \\
\text { excess ycerol }\end{array}$ & $\begin{array}{c}\text { Initial FFA } \\
(\%)\end{array}$ & $\begin{array}{c}\text { Final FFA } \\
(\%)\end{array}$ & Sources \\
\hline Rice Bran oil & 6 & 200 & p-toluene sulphonic acid & $50 \%$ & 15.3 & 1.6 & [42] \\
\hline Rice Bran oil & 6 & 200 & p-toluene sulphonic acid & $50 \%$ & 20.5 & 3.1 & \\
\hline Rice Bran oil & 4 & 200 & $\mathrm{SnCl}_{2}$ & $70 \%$ & 24.3 & 3.0 & [43] \\
\hline Rice Bran oil & 6 & 200 & $\mathrm{SnCl}_{2}$ & $0 \%$ & 64.7 & 0.9 & [39] \\
\hline Rubber seed oil & 6 & 200 & $\mathrm{ZnCl}_{2}$ & $4.3 \%$ & 37.69 & 1.5 & [45] \\
\hline $\begin{array}{l}\text { Mixed fatty acids obtained by } \\
\text { saponification of peanut oil }\end{array}$ & 4 & 200 & $\mathrm{SnC}_{4} \cdot 5 \mathrm{H} 20$ & Stoichiometric amount & 90.3 & 1.8 & [46] \\
\hline Waste cooking oil & 4 & 200 & $\mathrm{SO}_{4}^{2} / \mathrm{ZrO}_{2}-\mathrm{Al}_{2} \mathrm{O}_{3}$ & $70 \%$ & 44.42 & 0.707 & [47] \\
\hline Castor oil & 2 & 120 & No catalyst & $100 \%$ & $2.36 \%$ & $0.22 \%$ & [48] \\
\hline
\end{tabular}


removal steps.

\section{Acknowledgements}

The authors wish to acknowledge the Universiti Sains Malaysia for laboratory work and ESEPRIT project at University of Dar es Salaam under for financial support.

\section{REFERENCES}

[1] K. Alekett, "World Oil and Gas 'Running Out'," CNN, 2003.

http://edition.cnn.com/2003/WORLD/europe/10/02/globa l.warming/index.html

[2] J. Van Gerpen, "Biodiesel Processing and Production," Fuel Processing Technology, Vol. 86, No. 10, 2005, pp. 1097-1107.

http://dx.doi.org/10.1016/j.fuproc.2004.11.005

[3] L. C. Meher, D. Vidya Sagar and S. N. Naik, "Technical Aspects of Biodiesel Production by TransesterificationA Review," Renewable and Sustainable Energy Reviews, Vol. 10, No. 3, 2006, pp. 248-268. http://dx.doi.org/10.1016/j.rser.2004.09.002

[4] M. Kim, C. DiMaggio, S. Yan, S. O. Salley and K. Y. S. $\mathrm{Ng}$, "The Synergistic Effect of Alcohol Mixtures on Transesterification of Soybean Oil Using Homogeneous and Heterogeneous Catalysts," Applied Catalysis A: General, Vol. 378, No. 2, 2010, pp. 134-143. http://dx.doi.org/10.1016/j.apcata.2010.02.009

[5] J. Zhang, S. Chen, R. Yang and Y. Yan, "Biodiesel Production from Vegetable Oil Using Heterogenous Acid and Alkali Catalyst," Fuel, Vol. 89, No. 10, 2010, pp. 2939-2944. http://dx.doi.org/10.1016/j.fuel.2010.05.009

[6] Z. Helwani, M. R. Othman, N. Aziz, J. Kim and W. J. N. Fernando, "Solid Heterogeneous Catalysts for Transesterification of Triglycerides with Methanol: A Review," Applied Catalysis A: General, Vol. 363, No. 1-2, 2009, pp. 1-10. http://dx.doi.org/10.1016/j.apcata.2009.05.021

[7] C. Ngamcharussrivichai, P. Totarat and K. Bunyakiat, "Ca and $\mathrm{Zn}$ Mixed Oxide as a heterogeneous Base Catalyst for Transesterification of Palm Kernel Oil," Applied Catalysis A: General, Vol. 341, No. 1-2, 2008, pp. 77-85. http://dx.doi.org/10.1016/j.apcata.2008.02.020

[8] A. Kawashima, K. Matsubara and K. Honda, "Development of Heterogeneous Base Catalysts for Biodiesel Production," Bioresource Technology, Vol. 99, No. 9, 2008, pp. 3439-3443.

http://dx.doi.org/10.1016/j.biortech.2007.08.009

[9] J. Boro, D. Deka and A. J. Thakur, “A Review on Solid Oxide Derived from Waste Shells as Catalyst for Biodiesel Production," Renewable and Sustainable Energy Reviews, Vol. 16, No. 1, 2012, pp. 904-910. http://dx.doi.org/10.1016/j.rser.2011.09.011

[10] M. Zabeti, W. M. A. Wan Daud and M. K. Aroua, "Activity of Solid Catalysts for Biodiesel Production: A Review," Fuel Processing Technology, Vol. 90, No. 6, 2009, pp. 770-777.

http://dx.doi.org/10.1016/j.fuproc.2009.03.010
[11] M. Di Serio, R. Tesser, L. Pengmei and E. Santacesaria, "Heterogeneous Catalysts for Biodiesel Production," Energy \& Fuels, Vol. 22, No. 1, 2008, pp. 207-217.

[12] A. P. Chouhan and A. K. Sarma, "Modern Heterogeneous Catalysts for Biodiesel Production: A Comprehensive Review," Renewable and Sustainable Energy Reviews, Vol. 15, No. 9, 2011, pp. 4378-4399. http://dx.doi.org/10.1016/j.rser.2011.07.112

[13] Z. Helwani, M. R. Othman, N. Aziz, W. J. N. Fernando and J. Kim, "Technologies for Production of Biodiesel Focusing on Green Catalytic Techniques: A Review," Fuel Processing Technology, Vol. 90, No. 12, 2009, pp. 1502-1514. http://dx.doi.org/10.1016/j.fuproc.2009.07.016

[14] D. Bacovsky, W. Körbitz, M. Mittelbach and M. Wörgetter, "Biodiesel Production: Technologies and European Providers," Report T39-B6, 2007.

[15] Y. Zhang, M. A. Dube, D. D. McLean and M. Kates, "Biodiesel Production from Waste Cooking Oil: 1. Process Design and Technological Assessment," Bioresource Technology, Vol. 89, No. 1, 2003, pp. 1-16. http://dx.doi.org/10.1016/S0960-8524(03)00040-3

[16] J. Van Kasteren and A. Nisworo, "A Process Model to Estimate the Cost of Industrial Scale Biodiesel Production from Waste Cooking Oil by Supercritical Transesterification," Resources, Conservation and Recycling, Vol. 50, No. 4, 2007, pp. 442-458. http://dx.doi.org/10.1016/j.resconrec.2006.07.005

[17] J. M. Encinar, J. F. Gonzalez and A. Rodriguez-Reinares, "Biodiesel from Used Frying Oil. Variables Affecting the Yields and Characteristics of the Biodiesel," Industrial \& Engineering Chemistry Research, Vol. 44, No. 15, 2005 , pp. 5491-5499. http://dx.doi.org/10.1021/ie040214f

[18] A. B. Chhetri, M. S. Tango, S. M. Budge, K. C. Watts and M. R. Islam, "Non-Edible Plant Oils as New Sources for Biodiesel Production," International Journal of Molecular Sciences, Vol. 9, No. 2, 2008, p. 169. http://dx.doi.org/10.3390/ijms9020169

[19] T. Krawczyk, "Biodiesel-Alternative Fuel Makes Inroads but Hurdles Remain," Inform, Vol. 7, 1996, pp. 801-815.

[20] M. M. Gui, K. T. Lee and S. Bhatia, "Feasibility of Edible Oil vs. non-Edible Oil vs. Waste Edible Oil as Biodiesel Feedstock," Energy, Vol. 33, No. 11, 2008, pp. 1646-1653. http://dx.doi.org/10.1016/j.energy.2008.06.002

[21] Y. C. Sharma and B. Singh, "Development of Biodiesel: Current Scenario," Renewable and Sustainable Energy Reviews, Vol. 13, No. 6-7, 2009, pp. 1646-1651. http://dx.doi.org/10.1016/j.rser.2008.08.009

[22] A. E. Atabani, A. S. Silitonga, I. A. Badruddin, T. M. I. Mahlia, H. H. Masjuki and S. Mekhilef, "A Comprehensive Review on Biodiesel as an Alternative Energy Resource and Its Characteristics," Renewable and Sustainable Energy Reviews, Vol. 16, No. 4, 2012, pp. 20702093. http://dx.doi.org/10.1016/j.rser.2012.01.003

[23] H. J. Berchmans and S. Hirata, "Biodiesel Production from Crude Jatropha curcas L. Seed Oil with a High Content of Free Fatty Acids," Bioresource Technology, 
Vol. 99, No. 6, 2008, pp. 1716-1721.

http://dx.doi.org/10.1016/j.biortech.2007.03.051

[24] S.-Y. No, "Inedible Vegetable Oils and Their Derivatives for Alternative Diesel Fuels in CI Engines: A Review," Renewable and Sustainable Energy Reviews, Vol. 15, No. 1, 2011, pp. 131-149.

http://dx.doi.org/10.1016/j.rser.2010.08.012

[25] C. C. Enweremadu and M. M. Mbarawa, "Technical Aspects of Production and Analysis of Biodiesel from Used Cooking Oil-A Review," Renewable and Sustainable Energy Reviews, Vol. 13, No. 9, 2009, pp. 2205-2224. http://dx.doi.org/10.1016/j.rser.2009.06.007

[26] B. Freedman, E. H. Pryde and T. L. Mounts, "Variables Affecting the Yields of Fatty Esters from Transesterified Vegetable Oils," Journal of the American Oil Chemists' Society, Vol. 61, 1984, pp. 1638-1643.

[27] M. Canakci and J. Van Gerpen, "Biodiesel Production from Oils and Fats with High Free Fatty Acids," 1999.

[28] M. A. Hanna and F. Ma, "Biodiesel Production: A Review," Bioresource Technology, Vol. 70, 1999, pp. 1-15.

[29] J. M. Marchetti, V. U. Miguel and A. F. Errazu, "Possible Methods for Biodiesel Production," Renewable and Sustainable Energy Reviews, Vol. 11, No. 6, 2007, pp. 13001311. http://dx.doi.org/10.1016/j.rser.2005.08.006

[30] C. Tongurai, S. Klinpikul, C. Bunyakan and P. Kiatsimkul, "Biodiesel Production from Palm Oil," Songklanakarin Journal of Science and Technology, Vol. 23, 2001, pp. 832-841.

[31] G. Knothe, J. Van Gerpen and J. Krahl, "Basics of the Transesterification Reaction," In: The Biodiesel Handbook, AOCS Press, Champaign, 2005, pp. 26-41.

[32] M. Dorado, E. Ballesteros, J. De Almeida, C. Schellert, H. Löhrlein and R. Krause, "An Alkali-Catalyzed Transesterification Process for High Free Fatty Acid Waste Oils," Transactions of the ASAE, Vol. 45, 2002, pp. 525-529.

[33] A. Kumar, A. Kumar Tiwari and H. Raheman, "Biodiesel Production from Jatropha Oil (Jatropha curcas) with High Free fatty Acids: An Optimized Process," Biomass and bioenergy, Vol. 31, No. 8, 2007, pp. 569-575. http://dx.doi.org/10.1016/j.biombioe.2007.03.003

[34] S. V. Ghadge and H. Raheman, "Biodiesel Production from Mahua (Madhuca indica) Oil Having High Free Fatty Acids," Biomass and Bioenergy, Vol. 28, No. 6, 2005, pp. 601-605.

http://dx.doi.org/10.1016/j.biombioe.2004.11.009

[35] M. Sheng, D. L. Tian and G. M. Cao, "Production of Biodiesel Fuel from Wast Edible Oil," China Academic Journals, Vol. 26, 2008.

[36] D. Y. C. Leung, X. Wu and M. K. H. Leung, "A Review on Biodiesel Production Using Catalyzed Transesterification," Applied Energy, Vol. 87, No. 1, 2010, pp. 10831095. http://dx.doi.org/10.1016/j.apenergy.2009.10.006
[37] J. Van Gerpen, B. Shanks, R. Pruszko, D. Clements and G. Knothe, "Biodiesel Production Technology," Department of Energy, Washington DC, 2004.

[38] A. J. C. Anderson, "Refining of Oils and Fats for Edible Purposes," 2nd Edition, Pergamon Press, London, 1962, pp. 92-103.

[39] B. M. Bhosle and R. Subramanian, "New Approaches in Deacidification of Edible Oils-A Review," Journal of Food Engineering, Vol. 69, No. 4, 2005, pp. 481-494. http://dx.doi.org/10.1016/j.jfoodeng.2004.09.003

[40] M. Blanco, R. Beneyto, M. Castillo and M. Porcel, “Analytical Control of an Esterification Batch Reaction between Glycerine and Fatty Acids by Near-Infrared Spectroscopy," Analytica Chimica Acta, Vol. 521, No. 2, 2004, pp. 143-148. http://dx.doi.org/10.1016/j.aca.2004.06.003

[41] P. Felizardo, J. Machado, D. Vergueiro, M. J. N. Correia, J. P. Gomes and J. M. Bordado, "Study on the Glycerolysis Reaction of High Free Fatty Acid Oils for Use as Biodiesel Feedstock," Fuel Processing Technology, Vol. 92, No. 6, 2011, pp. 1225-1229. http://dx.doi.org/10.1016/i.fuproc.2011.01.020

[42] A. C. Bhattacharyya and D. K. Bhattacharyya, "Deacidification of High FFA Rice Bran Oil by Reesterification and Alkali Neutralization," Journal of the American Oil Chemists' Society, Vol. 64, No. 1, 1987, pp. 128-131.

[43] S. Singh and R. P. Singh, "Deacidification of High Free Fatty Acid-Containing Rice Bran Oil by Non-Conventional Reesterification Process," Journal of Oleo Science, Vol. 58, No. 2, 2009, pp. 53-56.

[44] B. K. De and D. K. Bhattacharyya, "Deacidification of High-Acid Rice Bran Oil by Reesterification with Monoglyceride," Journal of the American Oil Chemists' Society, Vol. 76, No. 10, 1999, pp. 1243-1246.

[45] R. O. Ebewele, A. F. Iyayi and F. K. Hymore, "Deacidification of High Acidic Rubber Seed Oil by Reesterification with Glycerol," International Journal of the Physical Sciences, Vol. 5, No. 6, 2010, pp. 841-846.

[46] R. Feuge, E. Kraemer and A. Bailey, "Modification of Vegetable Oils. IV. Reesterification of Fatty Acids with Glycerol," Journal of the American Oil Chemists' Society, Vol. 22, No. 8, 1945, pp. 202-207.

[47] Y. Wang, S. Ma, L. Wang, S. Tang, W. W. Riley and M. J. T. Reaney, "Solid Superacid Catalyzed Glycerol Esterification of Free Fatty Acids in Waste Cooking Oil for Biodiesel Production," European Journal of Lipid Science and Technology, Vol. 114, No. 3, 2012, pp. 315-324.

[48] L. L. Sousa, I. L. Lucena and F. A. N. Fernandes, "Transesterification of Castor Oil: Effect of the Acid Value and Neutralization of the Oil with Glycerol," Fuel Processing Technology, Vol. 91, No. 2, 2010, pp. 194-196. http://dx.doi.org/10.1016/j.fuproc.2009.09.016 